\section{Cooling Performances on Rainless Days of Extensive Green Roofs Planted with Different Ornamental Species}

\author{
Yann-Jou Lin \\ Department of Horticulture and Landscape Architecture, National Taiwan \\ University, No. 138, Sec. 4, Keelung Rd., Taipei, 10673 Taiwan (R.O.C.)
}

\section{Ai-Tsen Su}

Department of Social and Regional Development, National Taipei University of Education, No.134, Sec. 2, Heping E. Rd., Taipei, 10671 Taiwan (R.O.C.)

\author{
Bau-Show Lin ${ }^{1}$ \\ Department of Horticulture and Landscape Architecture, National Taiwan \\ University, No. 138, Sec. 4, Keelung Rd., Taipei, 10673 Taiwan (R.O.C.)
}

Additional index words. roof greening, plant characteristics, seasonal variation, plant selection

Abstract. This study investigated the cooling performances of extensive green roofs (EGRs) planted with 12 ornamental plants on rainless days in a subtropical city for 1 year. Imitating the construction of an EGR, 48 modules were constructed and each module was planted as a monoculture with 100 plants each. Plant growth and greening performance were measured every 2 weeks. Temperatures, solar radiation intensities, and substrate water contents were measured continuously and recorded every 5 minutes. The analyzed results showed that both plant species selection and seasonal variation had a significant impact on the noontime cooling benefit. The modules planted with taller plants, more extensive plant cover, higher albedo, and greater canopy volume had a greater noontime cooling benefit. As the seasons changed, the albedo and canopy volume of the modules were primarily responsible for differences in the noontime cooling benefit provided by the different plant species. Over an entire year of observation, the results of this research could inform the selection of plant species by landscape designers for EGRs with the aim of providing greater cooling benefits and aesthetic quality overall four seasons.
Many studies have proven that green roofs provide ecological services such as regulating temperature (Bevilacqua et al., 2016; BucklandNicks et al., 2016; Dvorak and Volder, 2013; Lin et al., 2013; Kumar and Kaushik, 2005; Wong et al., 2007), managing stormwater (Mentens et al., 2006; Razzaghmanesh et al., 2014; Schroll et al., 2011; Stovin et al., 2015), improving air quality (Baik et al., 2012; Jun et al., 2008; Rowe, 2011; Tong et al., 2016), and promoting urban biodiversity (Francis and Lorimer, 2011; Gedge and Kadas, 2005; Madre et al., 2014; Van Mechelen et al., 2014). However, mitigating the urban heat island effect and managing stormwater are the primary reasons that various cities promote green roofs.

The vegetation layer is one of the most important structural components of an EGR and is the outermost layer of the green roof structure. Its design is influenced by environmental factors that are detrimental to plant growth, such as the thickness of the substrate layer, drought, strong winds, and large

Received for publication 20 Oct. 2016. Accepted for publication 28 Dec. 2016.

We would like to thank National Science Council of Taiwan for research grant support of this research under contract no. NSC 99-2410-H-002-185-MY3. ${ }^{1}$ Corresponding author. E-mail: doralin@ntu. edu.tw. variations in temperature, so there are many limitations affecting plant selection. Suitable plant species must be heat tolerant, drought tolerant, wind tolerant, and cold tolerant as well as tolerant of barren substrates and diseases and pests (Dunnett and Kingsbury, 2004; Getter and Rowe, 2006). Suitable plant species are most commonly short and creeping in appearance with shallow roots; they are also easy to propagate, have a strong capacity for self-seeding, and provide extensive plant cover (White and Snodgrass, 2003). Therefore, common suitable species include plants of the family Crassulaceae, succulents, groundcover plants, bryophytes, and short shrubs; shallow-rooted native plants can also be used for EGRs (Getter and Rowe, 2006).

The selection of plant species is also quite important to the cooling and energy-saving benefits provided by EGRs and has been one of the key subjects of recent research (Blanusa et al., 2013; Lin, 2010; Lundholm, 2015; Lundholm et al., 2014; Wong et al., 2007; Zhao et al., 2014). Studies have shown that the cooling performance of a green roof differs with the use of different plant species (Blanusa et al., 2013; Getter et al., 2011; Lin, 2010; Wong et al., 2007; Zhao et al., 2014). Researchers have recently focused on quantifying the effects of plant characteristics on cooling (Benvenuti, 2014; Bevilacqua et al., 2015; Jim, 2014; Olivieri, et al., 2013; TabaresVelasco and Srebric, 2011; Yaghoobian and Srebric, 2015). These characteristics include plant coverage, plant height, albedo, stomatal resistance, and photosynthetic pathway, and the leaf area index (LAI), which represents foliage density and is the ratio of area of the leaves to the area of the ground under the canopy (Kumar and Kaushik, 2005).

Research on EGRs also includes such subjects as personal landscape preference (Lee et al., 2014; Loder, 2014; Jungels et al., 2013) and other psychological benefits (Lee et al., 2014). In terms of visual aesthetics, plant characteristics such as foliage density, green coverage, foliage color, flowering habit, and plant height impact the visual

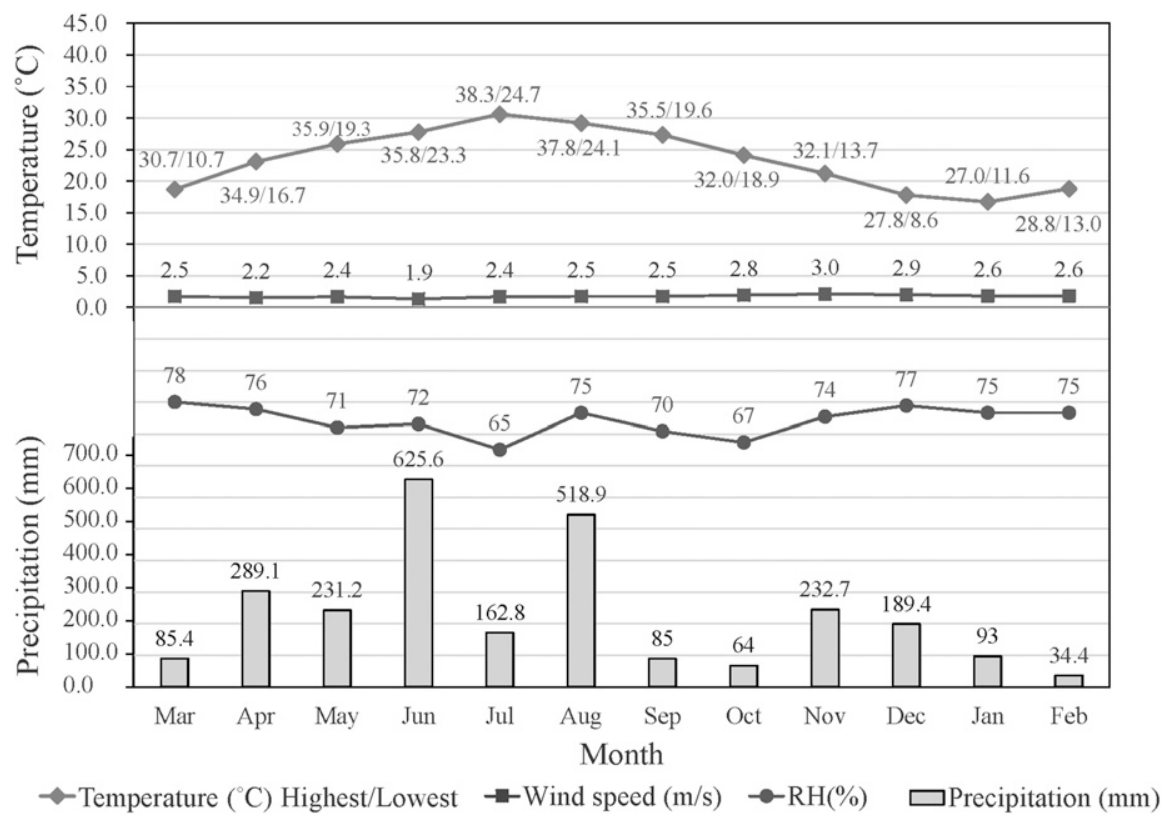

Fig. 1. Weather statistics for Taipei in the period of Mar. 2012-Feb. 2013. 
Table 1. Names and general information about the 12 plant species.

\begin{tabular}{|c|c|c|c|c|c|c|}
\hline Scientific name & $\begin{array}{l}\text { Common } \\
\text { name }\end{array}$ & $\begin{array}{l}\text { Plant } \\
\text { habit }\end{array}$ & $\begin{array}{c}\text { Plant } \\
\text { density }\end{array}$ & $\begin{array}{l}\text { Growth } \\
\text { rate }\end{array}$ & Leaf color & Flower \\
\hline Codiaeum variegatum var. pictum & Croton & Upright & Moderate & Slow & Yellow & Inconspicuous \\
\hline Ophiopogon japonicus 'Nanus' & Mondo grass & Spreading & Dense & Slow & Dark green & Summer/white \\
\hline Alternanthera ficoidea 'New Red' & Red threads & Spreading & Moderate & Medium & Red & Year-round/white \\
\hline Wedelia trilobata (L.) Hitchc. & Wedelia & Spreading & Dense & Fast & Green & Year-round/yellow \\
\hline Zebrina pendula Schnizl. & Wandering jew & Spreading & Moderate & Fast & $\begin{array}{l}\text { Alternate purplish } \\
\text { red and green stripes }\end{array}$ & Year-round/pink \\
\hline Belamcanda chinensis & Blackberry lily & Upright & Moderate & Medium & Green & Summer to autumn/yellow \\
\hline Schizocentron elegans & Spanish shawl & Spreading & Moderate & Fast & Green & Summer to autumn/pink \\
\hline Plectranthus amboinicus & Spanish thyme & Upright & Dense & Fast & Green & Spring/light purple \\
\hline Sansevieria trifasciata 'Laurentii' & Snake plant & Upright & Dense & Medium & $\begin{array}{l}\text { Dark green with yellow } \\
\text { leaf edges }\end{array}$ & Late autumn/light yellow \\
\hline Sedum lineare 'Variegatum' & Carpet sedum & Spreading & Moderate & Fast & $\begin{array}{l}\text { Light green with white } \\
\text { leaf edges }\end{array}$ & Spring/yellow \\
\hline Tulbaghia violacea & Wild garlic & Upright & Moderate & Fast & Dark green & Year round/purple \\
\hline $\begin{array}{l}\text { Ophiopogon intermedius } \\
\text { 'Argenteo-marginatus' }\end{array}$ & Lily turf & Spreading & Dense & Slow & Dark green & Summer/white \\
\hline
\end{tabular}

Referring to Chang (2004) and Hsueh and Yang (2014).

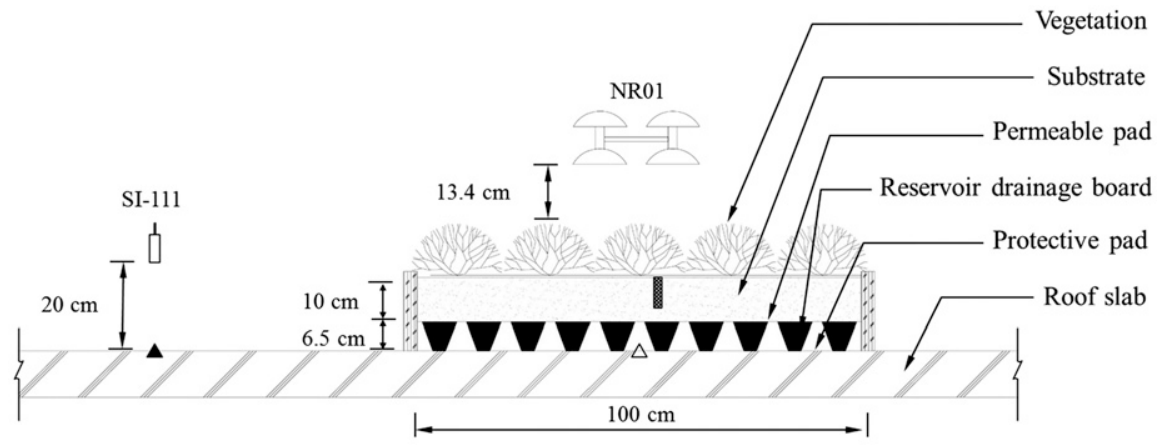

$\triangle$ Measuring point for reference point surface temperature

$\triangle$ Measuring point for module temperature

Measuring point for module volumetric water content

Fig. 2. The schematic diagram of an extensive green roof module and measuring positions.

preferences of people (Fernandez-Cañero et al., 2013; Loder, 2014). Thus plant characteristics affect both cooling effects and visual quality.

An EGR with a stronger cooling effect that is more preferred visually could increase its favorability among the general public, but plant characteristics and greening performance differ with the choice of plant species and vary seasonally. Therefore, the objective of this study was to investigate the cooling performances of EGRs planted with different ornamental species overall four seasons. Since previous studies (Jim and Peng, 2012; Lin et al., 2013) have shown that precipitation influences the cooling effects of green roofs, data collected on rainless days were analyzed. Over an entire year of observation, the results of this research could inform the selection of plant species by landscape designers for EGRs with the aim of providing greater cooling benefits and aesthetic quality overall four seasons.

\section{Materials and Methods}

In the present study, modules were built to simulate an EGR system. Observations and data collection were conducted over an entire year from 1 Mar. 2012 to 28 Feb. 2013.
Experimental roof. The roof of the Landscape Architecture Building $\left(25^{\circ} 00^{\prime} \mathrm{N}\right.$, $121^{\circ} 32^{\prime} \mathrm{E}$ ) of the National Taiwan University in Taipei, Taiwan, was chosen for the experiment. This roof is a flat roof with a total area of $536.5 \mathrm{~m}^{2}$. To avoid the influence of the shade of the parapet, water towers, and other extensions of the building, the shadow on the roof was analyzed, and the area that was not influenced by shadow was designated as the experimental area.

During the observation period, the mean temperature in Taipei was $\approx 23.4{ }^{\circ} \mathrm{C}$; the highest temperature was $\approx 38.3{ }^{\circ} \mathrm{C}$ (July, summer); and the lowest temperature was $\approx 8.6{ }^{\circ} \mathrm{C}$ (December, winter). The total precipitation for the year was $\approx 2611.5 \mathrm{~mm}$, and the mean wind speed and relative humidity were $2.5 \mathrm{~m} \cdot \mathrm{s}^{-1}$ and $73 \%$, respectively (Fig. 1).

Plant materials. Twelve ornamental plants that are most commonly used for EGRs in Taiwan were selected for the study (Table 1). A completely randomized design was adopted, and four replicates were designed for the 12 plant species. Therefore, 48 modules were constructed, and each module was planted as a monoculture with 100 plants each. Planting materials were purchased from a commercial nursery, and the plants were cultivated in $7.5-\mathrm{cm}$ flowerpots in a substrate with a volume ratio of peat soil:rice hulls:sand of $3: 1: 1$. Before being transplanted from the flowerpots to the modules, the plants were shaken to remove the excess substrate.

Construction of the modules. Imitating the construction of an EGR, each module included a protective pad (polyvinyl chloride waterproofing membranes, $1.5 \mathrm{~mm}$ thick, 300 $\mathrm{g} \cdot \mathrm{m}^{-2}$ ), four reservoir drainage boards [dimensions: $50 \times 50 \times 6.5 \mathrm{~cm}$ (width $\times$ depth $\times$ height, WDH); water retention: $4500 \mathrm{cc} /$ board], a permeable pad (nonwoven polypropylene geotextiles, $1.2 \mathrm{~mm}$ thick, $155 \mathrm{~g} \cdot \mathrm{m}^{-2}$ ), a substrate layer (10-cm thick), and a vegetation layer (bottom-up). The frame of each module had inner dimensions of $100 \times 100 \times$ $17.5 \mathrm{~cm}(\mathrm{WDH})$ and was constructed with southern pine lumber (2.5-cm thick).

The substrate formula followed that proposed by the Taipei His Liu Environmental Greening Foundation (2007), and the mix had a volume ratio of peat soil:coir: perlite: sand of $6: 1: 1: 2$. The bulk density and albedo of the substrate mix were $0.42 \mathrm{~g} \cdot \mathrm{cm}^{-3}$ and 0.075 , respectively, and the volumetric water content (VWC) of the saturated substrate was $\approx 0.465 \mathrm{~m}^{3} \cdot \mathrm{m}^{-3}$.

Observations and data collection were conducted after 1 month of maintenance. An automatic irrigation system was used for water management during the observation period; four Shrubbler $360^{\circ}$ drippers (flow: $0.6612 \mathrm{~L} \cdot \mathrm{min}^{-1}$; Antelco Pty Ltd., South Australia, Australia) were mounted in the center of the four quarters of each module. The plants were automatically irrigated for 5 min at 6 AM every day as early results showed that it took $\approx 5 \mathrm{~min}$ for the substrate to reach full capacity (irrigation controller: YIU TSAY Co., LTD., Taipei, Taiwan).

Measurement of plant growth and greening performance. Plant growth and greening performance were measured every 2 weeks. Measurements included plant height, plant coverage, and albedo.

A measuring tape was used to measure the plant height of three randomly selected plants from each module. A photographic method 


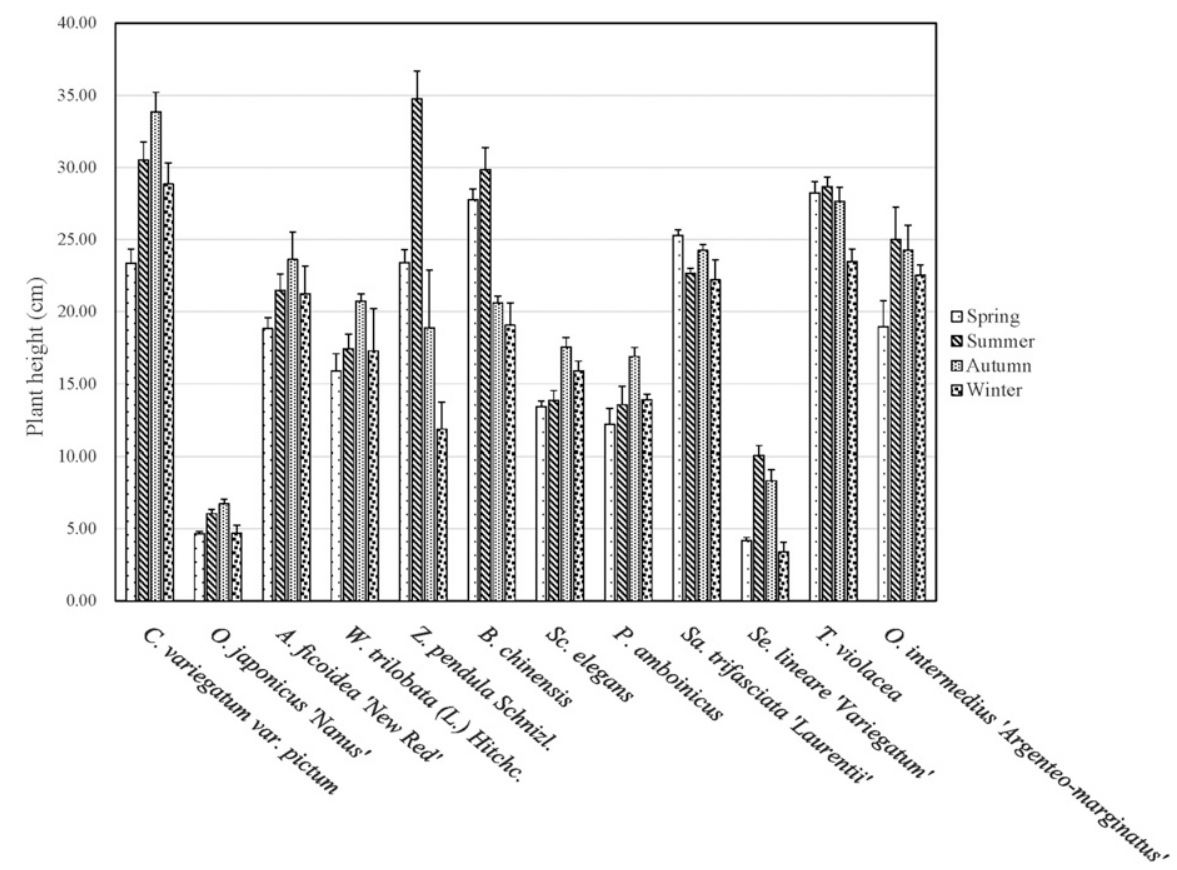

Fig. 3. Mean height of the 12 plant species over the course of four seasons.

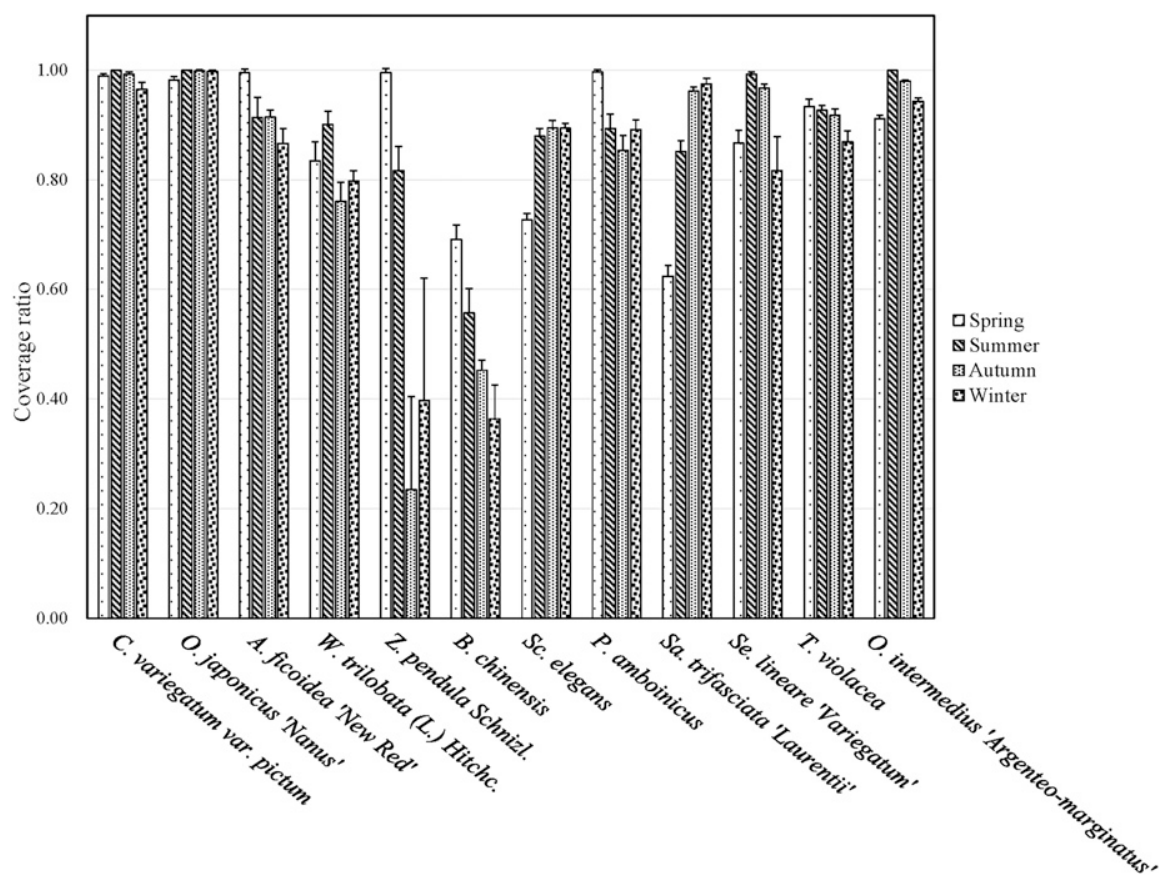

Fig. 4. Mean plant coverage of the 12 plant species over the course of four seasons.

was used to determine plant coverage; a Nikon D7000 camera (Nikon Inc., Long Island, NY) was used to take a photograph of each module with the camera lens positioned parallel to the ground. Adobe Photoshop software for Windows (Version CS4; Adobe Systems Incorporated, San Jose, CA) was then used to analyze the plant coverage in each module as follows:

1) The Crop tool was used to trim the image to show only the module.

2) A black-and-white adjustment layer was created, and the color filter
5) In the menu, Analysis $>$ Set Measurement Scale $>$ Custom was chosen, and the tool was dragged to measure the length of the module in pixels. One was entered for Logical Length.

6) In the menu, Analysis > Record Measurements was chosen to show the measurement $\log$. The value in the area column was the plant coverage of the module.

An NR01 four-component net radiation sensor (Campbell Scientific, Inc., Logan, UT; accuracy: $\pm 10 \%$ for daily sums) was used to measure the albedo of each module. The sensor was placed perpendicularly in the center of the module at a distance of $\approx 13.4 \mathrm{~cm}$ above the surface of the vegetation.

Previous studies have indicated that LAI is an important factor in determining the cooling effect provided by plants (Lin and Lin, 2010; Sailor, 2008). According to Olsoy et al. (2015), canopy volume is a good predicator of LAI, so canopy volume was used instead of LAI in this study. The canopy volume was calculated as plant coverage area multiplied by plant height.

Monitoring of the cooling benefits. A location within the experimental area, a bare white roof with no experimental modules, was set as a reference point. The temperature at the reference point was measured with an SI-111 Precision Infrared Radiometer (Campbell Scientific, Inc.; uncertainty: $\pm 0.2{ }^{\circ} \mathrm{C}$ ) was mounted perpendicular to the surface of the reference point at a height of $20 \mathrm{~cm}$, and the measurement area was $267.5 \mathrm{~cm}^{2}$. A thermocouple wire (type T, uncertainty $(k=2): \pm 0.4{ }^{\circ} \mathrm{C}$ ) was used to measure the temperature of the roof surface below each module.

The four components of solar radiation including incoming shortwave radiation $\left(\mathrm{SR}_{\mathrm{in}}\right)$, outgoing shortwave radiation $\left(\mathrm{SR}_{\mathrm{out}}\right)$, incoming longwave radiation ( $\left.I R_{\text {in }}\right)$, and outgoing longwave radiation $\left(\mathrm{IR}_{\mathrm{out}}\right)$ reaching the roof were monitored by an NR01 fourcomponent net radiation sensor. Net radiation $\left(R_{n}\right)$ was defined as the balance between the incoming and outgoing radiation: $\mathrm{R}_{\mathrm{n}}=$ $\left(\mathrm{SR}_{\text {in }}-\mathrm{SR}_{\text {out }}\right)+\left(\mathrm{IR}_{\mathrm{i}}-\mathrm{IR}_{\text {out }}\right)$. The substrate water content of each module (VWC) was monitored using an EC-5 soil moisture sensor (Decagon Devices, Inc., Pullman, WA; uncertainty: $\pm 0.02 \mathrm{~m}^{3} \cdot \mathrm{m}^{-3}$ ).

The SI-111 Precision Infrared Radiometer, the thermocouple wires, the EC-5 sensor, and the NR01 four-component net radiation sensor were connected to CR-1000 data loggers (Campbell Scientific, Inc.) to record the measurements every $5 \mathrm{~min}$. Figure 2 shows the schematic diagram of the measurement positions for the modules and the reference point.

Statistical analysis. According to the Central Weather Bureau (2012-13), days are considered rainy when the daily cumulative precipitation is greater than $0.1 \mathrm{~mm}$. Based on precipitation data from the nearby Taipei Weather Station (Central Weather Bureau, 2012-13), the data from each rainy day and the following day were excluded. Data from a total of $101 \mathrm{~d}$ were analyzed including 


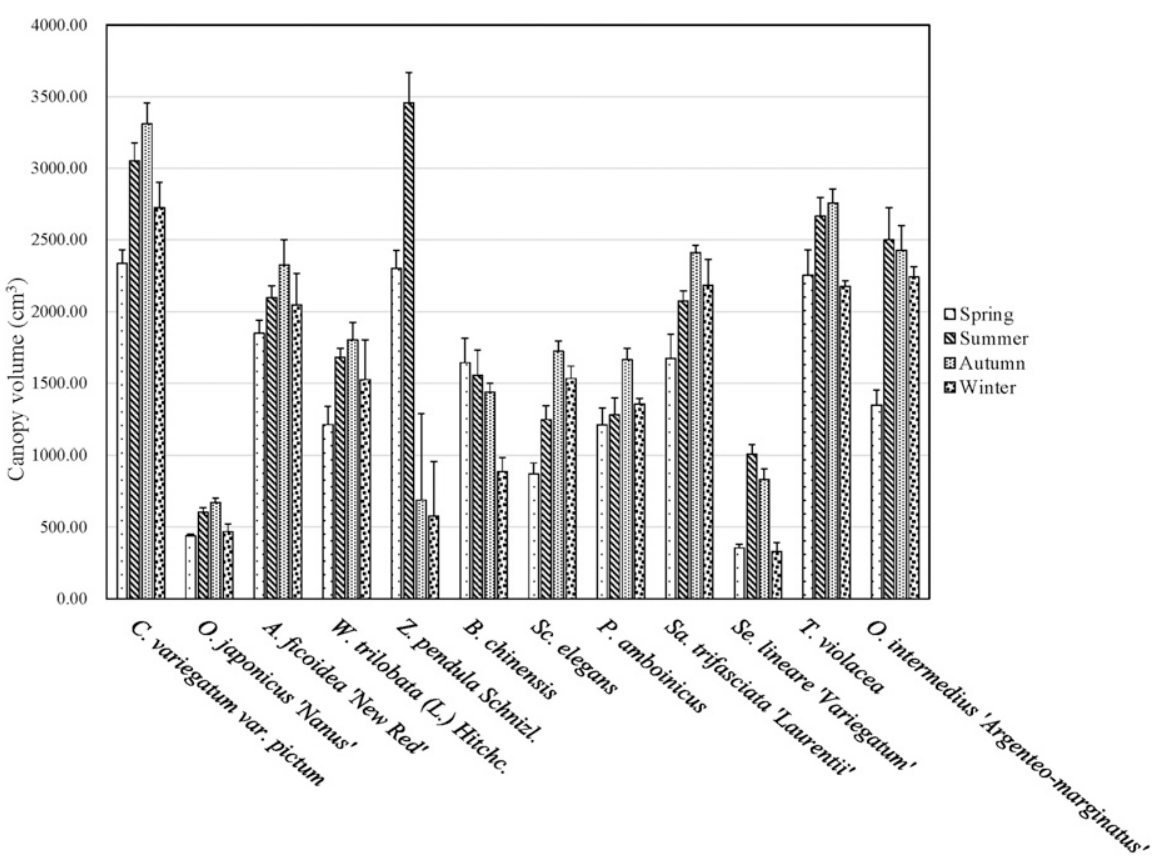

Fig. 5. Mean canopy volume of the extensive green roof modules planted with the 12 plant species over the course of four seasons.

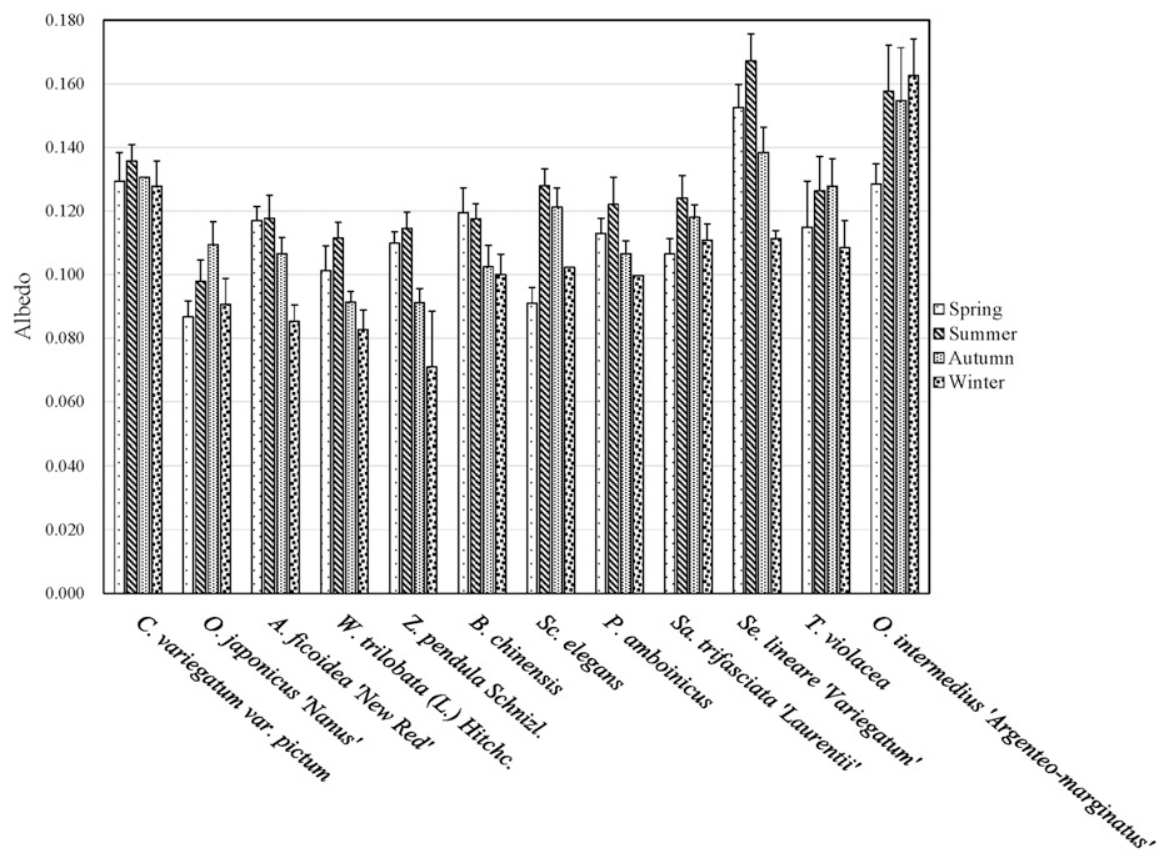

Fig. 6. Mean albedos of the extensive green roof modules planted with the 12 plant species over the course of four seasons.

temperature, radiation intensity, and VWC, which were recorded every 5 min on rainless days and averaged for each hour.

Since there was no practical reason to simulate an EGR without vegetation, the differences in cooling performance among the 12 ornamental plants were compared by quantifying the entire cooling benefit of each module, which was defined as the temperature of the module subtracted from the temperature at the reference point. The amplitude of the difference in the cooling benefit among the modules planted with the 12 plant
A Pearson's correlation coefficient $(r)$ was further used to measure the strength of the association between plant characteristics and its greening performance and cooling benefits. Furthermore, a stepwise multiple regression analysis was conducted to examine the relative contribution of plant characteristics and greening performance to the cooling benefit.

\section{Results}

Plant characteristics and greening performance and their seasonal variation. The 12 plant species differed in their characteristics and greening performance. As the seasons changed, differences between and within plant species were observed.

Plant height. Codiaeum variegatum var. pictum (mean height $=29.15 \mathrm{~cm}$ ) and Tulbaghia violacea $($ mean height $=27.01 \mathrm{~cm})$ were relatively tall, whereas Ophiopogon japonicus 'Nanus' (mean height $=5.53 \mathrm{~cm}$ ) and Sedum lineare 'Variegatum' (mean height $=$ $6.49 \mathrm{~cm}$ ) were relatively short.

Plant height varied seasonally; most of the plants were taller in the summer and autumn and shorter in the spring and winter. Among the 12 plant species, the heights of $O$. japonicus 'Nanus' $(\mathrm{sD}=0.92)$, Sansevieria trifasciata 'Laurentii' (SD = 1.31), Schizocentron elegans $(\mathrm{SD}=1.74)$, and Plectranthus amboinicus $(\mathrm{SD}=1.83)$ only changed slightly over the four seasons. The height of Zebrina pendula Schnizl. changed the most $(\mathrm{SD}=8.67)$ over the four seasons, being $\approx 34.74 \mathrm{~cm}$ in summer and $11.86 \mathrm{~cm}$ in winter (Fig. 3).

Plant coverage. The plant coverage of a module was related to the inherent characteristics of the study plant. Creeping plants with dense branches and leaves that grow quickly can easily attain extensive plant cover, but the coverages of the different plant species during the four seasons were also related to growth conditions. Coverage increased the most in plants that grew luxuriantly during the growing season, while the coverages of plants that withered significantly after the growing season rapidly decreased.

Among the 12 plant species, C. variegatum var. pictum, O. japonicus 'Nanus', Alternanthera ficoidea 'New Red', P. amboinicus, Se. lineare 'Variegatum', T. violacea, and Ophiopogon intermedius 'Argenteo-marginatus' exhibited relatively extensive plant cover (all were above $80 \%$ ). In contrast, the coverage of $Z$. pendula Schnizl. showed large seasonal variations; its foliage withered in autumn, resulting in a significant decrease in coverage but increased again in winter. The Belamcanda chinensis plants exhibited relatively low seasonal plant coverage, lower than $70 \%$ for all seasons. In fact, among the 12 plant species, only the coverage of $B$. chinensis showed a decreasing trend due to its inherent plant characteristics (Fig. 4).

Canopy volume. The canopy volume of the modules was also highly correlated with growth conditions. The canopy volumes of the modules planted with $C$. variegatum var. pictum, O. japonicus 'Nanus', A. ficoidea 'New Red', Wedelia trilobata (L.) Hitchc., 


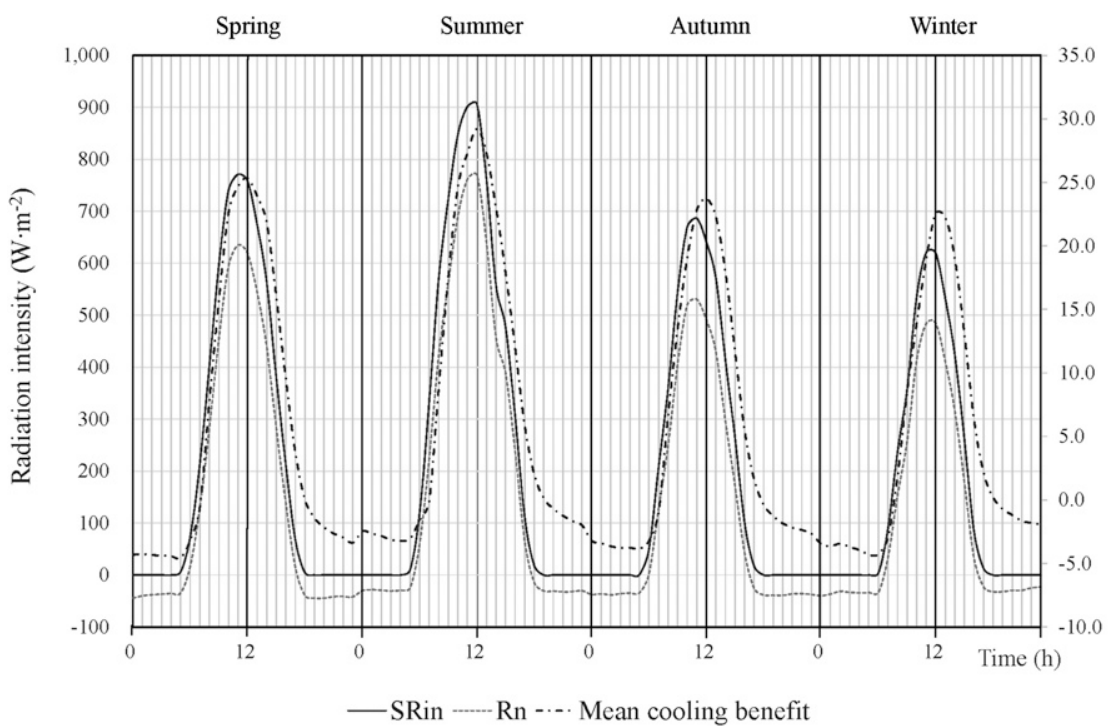

Fig. 7. Daily variation in incoming shortwave radiation $\left(\mathrm{SR}_{\mathrm{in}}\right)$, net radiation $\left(\mathrm{R}_{\mathrm{n}}\right)$, and mean cooling benefit of the extensive green roof modules over the course of four seasons.

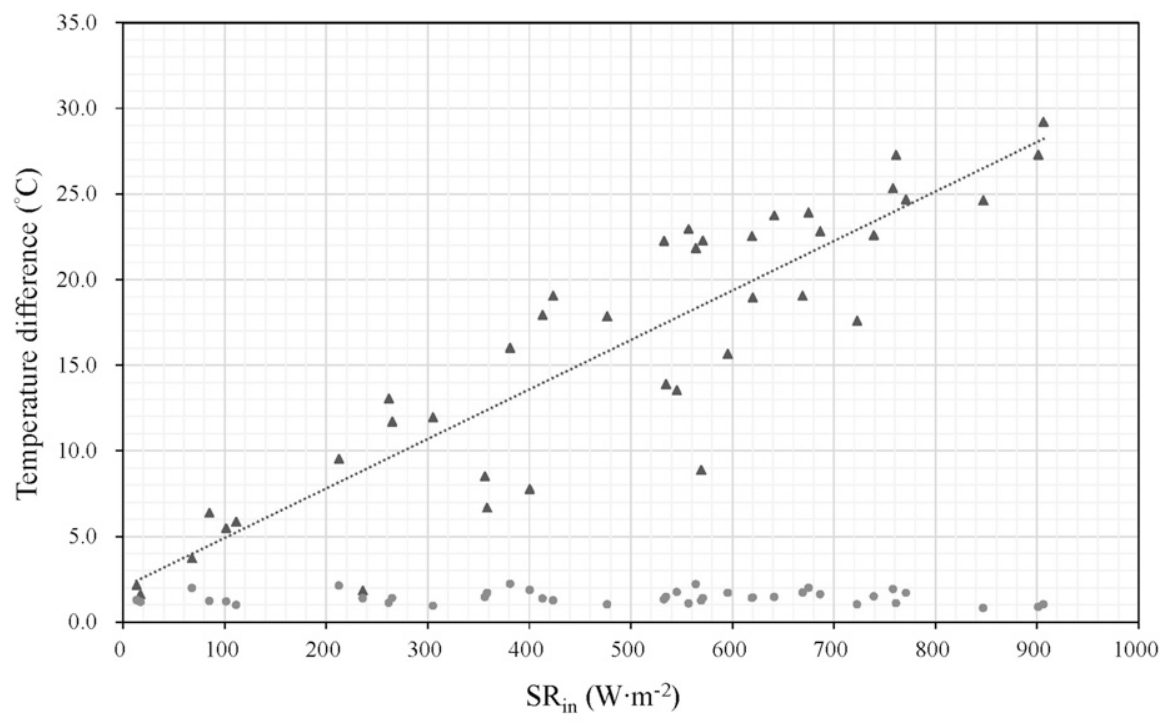

$\Delta$ Mean cooling benefit Amplitude of difference in cooling benefit

Fig. 8. Relationship among the mean cooling benefits, the amplitudes of difference in cooling benefit and incoming shortwave radiation $\left(\mathrm{SR}_{\mathrm{in}}\right)$.

Sc. elegans, P. amboinicus, Sa. trifasciata 'Laurentii', and T. violacea showed an increasing trend from spring to autumn, but those of the modules planted with $Z$. pendula Schnizl. significantly decreased in autumn and winter. Over the course of four seasons, the modules planted with $B$. chinensis showed a decreasing trend in canopy volume (Fig. 5).

Albedo. The albedos of the modules changed with the different plant species and seasons. The modules planted with Se. lineare 'Variegatum' (mean albedo $=0.151)$ and O. intermedius 'Argenteo-marginatus' (mean albedo $=0.142$ ) had relatively high annual mean albedos, whereas the modules planted with $O$. japonicus 'Nanus' (mean albedo = 0.096), W. trilobata (L.) Hitchc. (mean albedo $=0.097$ ) and $Z$. pendula Schnizl. (mean albedo $=0.097)$ had relatively low annual mean albedos.

Seasonal variation in the albedo of each module varied positively with the brightness of the plant leaf and flower color and plant coverage. There was a relatively large variation in the albedo of the module that planted with Se. lineare 'Variegatum' during the four seasons $(\mathrm{SD}=0.02)$. The Se. lineare 'Variegatum' plants grew most quickly during the summer, and their leaves were brightest in summer. The albedo of their module was, therefore, highest in summer (albedo = $0.167)$. However, the foliage of Se. lineare 'Variegatum' withered in autumn and winter, so its cover decreased, and the leaves were maroon in color during these two seasons. This resulted in decreased module albedo in both autumn (albedo $=0.138$ ) and winter $($ albedo $=0.111)$. There was little variation across the four seasons in the albedos of the modules planted with $C$. variegatum var. pictum $(\mathrm{SD}=0.01)$ (Fig. 6).

Variation and trends in daily radiation intensity and cooling benefits. In all four seasons, the intensity of the $\mathrm{SR}_{\text {in }}$ on sunny days began to climb between 05:00 and 06:00 and decreased to $\approx 0$ between 17:00 and 18:00; it peaked between 11:00 and 12:00 in all seasons. On average, the rates and peak intensities of the $\mathrm{SR}_{\text {in }}$ were highest in summer $\left(\right.$ mean $\left.=906 \mathrm{~W} \cdot \mathrm{m}^{-2}\right)$ followed by spring $\left(\right.$ mean $\left.=771 \mathrm{~W} \cdot \mathrm{m}^{-2}\right)$, autumn $($ mean $=$ $\left.687 \mathrm{~W} \cdot \mathrm{m}^{-2}\right)$, and winter $\left(\right.$ mean $\left.=620 \mathrm{~W} \cdot \mathrm{m}^{-2}\right)$. The $R_{n}$ on sunny days during the four seasons was mainly affected by the $\mathrm{SR}_{\mathrm{in}}$, so the daily variation in $R_{n}$ was similar to that of the $\mathrm{SR}_{\mathrm{in}}$. The $\mathrm{R}_{\mathrm{n}}$ peaked between 11:00 and 12:00. On average, the highest intensity occurred in summer (mean $=$ $\left.769 \mathrm{~W} \cdot \mathrm{m}^{-2}\right)$ followed by spring $($ mean $=635$ $\left.\mathrm{W} \cdot \mathrm{m}^{-2}\right)$, autumn $\left(\right.$ mean $\left.=531 \mathrm{~W} \cdot \mathrm{m}^{-2}\right)$, and winter $\left(\right.$ mean $\left.=485 \mathrm{~W} \cdot \mathrm{m}^{-2}\right)$ (Fig. 7).

The mean daily variation in the cooling benefits of the modules exhibited bell-shaped temperature curves during all four seasons. Cooling began to occur between 07:00 and 08:00, increased throughout the morning, peaked between 12:00 and 13:00, decreased during the afternoon, and fell to 0 between 18:00 and 19:00. At noontime, the cooling benefits of the EGRs were highest in summer followed by spring, autumn, and winter, so the daily and seasonal trend in the variation of the cooling benefits of EGR matched with the trend of the $\mathrm{SR}_{\mathrm{in}}$ and $\mathrm{R}_{\mathrm{n}}$. However, the peat cooling time lagged behind the peak $\mathrm{SR}_{\text {in }}$ and $\mathrm{R}_{\mathrm{n}}$ (Fig. 7).

The amplitude of the differences in the cooling benefits. The hourly amplitude of the difference in the cooling benefits among the modules planted with different plant species ranged from $0.8{ }^{\circ} \mathrm{C}$ to $2.2{ }^{\circ} \mathrm{C}$, and the mean amplitude was $\approx 1.4{ }^{\circ} \mathrm{C}$. Figure 8 illustrates that the cooling benefit of each module was linearly and positively related to the $\mathrm{SR}_{\text {in }}$, but the amplitude of the differences in the cooling benefits of the modules planted with different plant species was unaffected by $\mathrm{SR}_{\mathrm{in}}$.

Noontime cooling benefits of the modules. According to the peak hour of solar radiation and the cooling benefits of the modules, the period between 11:00 and 13:00 was selected to analyze the noontime cooling benefits.

The noontime roof surface temperature at the reference point was highest in summer $\left(57.4{ }^{\circ} \mathrm{C}\right)$ followed by spring $\left(48.1{ }^{\circ} \mathrm{C}\right)$, autumn $\left(46.9^{\circ} \mathrm{C}\right)$, and winter $\left(39.5^{\circ} \mathrm{C}\right)$, and the mean noontime roof surface temperature beneath the modules was also highest in summer $\left(29.4{ }^{\circ} \mathrm{C}\right)$ followed by autumn $\left(23.9^{\circ} \mathrm{C}\right)$ and spring $\left(23.5^{\circ} \mathrm{C}\right)$. The mean noontime roof surface temperature beneath the modules was lowest in winter $\left(18.2^{\circ} \mathrm{C}\right)$.

In summer, the high radiation quantity caused the surface temperature at the reference point and the surface temperatures beneath the modules to be much higher than those during the other seasons. However, the seasonal variation in the surface temperature 
at the reference point was larger than the seasonal variation in the surface temperature beneath each module, indicating that the EGR had the capacity to moderate temperature fluctuations (Table 2).

A $t$ test showed that the differences between the mean roof surface temperature at the reference point and that beneath the modules were significant, which indicates that the cooling effect of the modules was significant at noontime during all four seasons. The noontime cooling benefits of the modules were greater than $20{ }^{\circ} \mathrm{C}$ during all four seasons, with the mean noontime cooling

Table 2. Analysis of the mean noontime temperatures beneath the extensive green roof modules and at the reference point over the course of four seasons.

\begin{tabular}{|c|c|c|c|c|c|c|}
\hline \multirow[b]{2}{*}{ Temperature $\left({ }^{\circ} \mathrm{C}\right)$} & \multicolumn{2}{|c|}{ Reference point } & \multicolumn{2}{|c|}{ Module } & \multicolumn{2}{|c|}{ Temperature difference } \\
\hline & Mean & SD & Mean & SD & Mean & \\
\hline Spring & 48.1 & 0.5 & 23.5 & 0.7 & 24.7 & $* * *$ \\
\hline Summer & 57.4 & 0.9 & 29.4 & 0.4 & 27.9 & $* * *$ \\
\hline Autumn & 46.9 & 0.6 & 23.9 & 0.7 & 22.9 & $* * *$ \\
\hline Winter & 39.5 & 1.7 & 18.2 & 0.5 & 21.3 & $* * *$ \\
\hline Average & 48.0 & 6.5 & 23.8 & 4.0 & 24.2 & $* * *$ \\
\hline
\end{tabular}

The analysis period was 11:00 to 13:00.

$* * *$ refers to $P<0.001$.

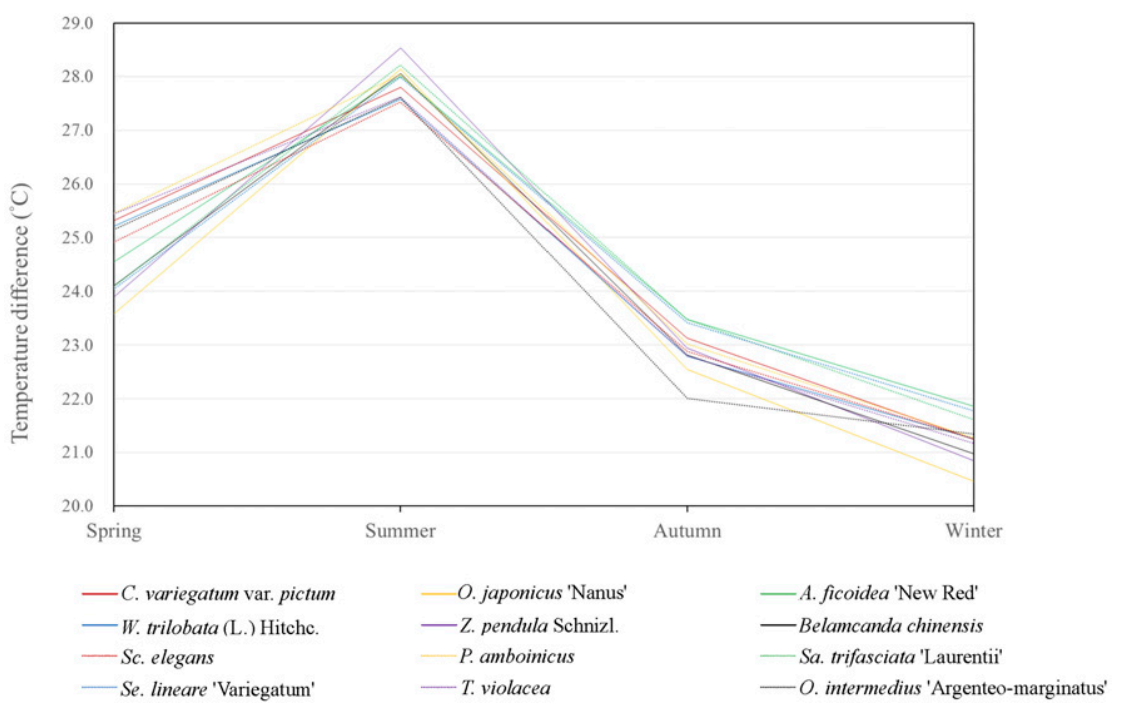

Fig. 9. Analysis of the noontime cooling benefits of different plant species in the extensive green roof modules over the course of four seasons. benefit of the modules being highest in summer $\left(27.9^{\circ} \mathrm{C}\right)$ followed by spring $\left(24.7^{\circ} \mathrm{C}\right)$, autumn $\left(22.9^{\circ} \mathrm{C}\right)$ and winter $\left(21.3^{\circ} \mathrm{C}\right)$ (Table 2).

The effects of plant species and seasonal variation on the noontime cooling benefit. Figure 9 shows that the noontime cooling benefits of the modules planted different plant species were significantly different, and the magnitude of the difference also varied with the season.

In the spring, modules planted with $P$. amboinicus and $T$. violacea had noontime cooling benefits of $\approx 25.4{ }^{\circ} \mathrm{C}$, and modules planted with $O$. japonicus 'Nanus' had a noontime cooling benefit of $\approx 23.6{ }^{\circ} \mathrm{C}$. In the summer, modules planted with $Z$. pendula Schnizl. had a noontime cooling benefit of $\approx 28.5{ }^{\circ} \mathrm{C}$, whereas those planted with $S c$. elegans had a benefit of $\approx 27.5{ }^{\circ} \mathrm{C}$. In the autumn, modules planted with $A$. ficoidea 'New Red' and Sa. trifasciata 'Laurentii' had noontime cooling benefits of $\approx 23.5^{\circ} \mathrm{C}$, and those planted with $O$. intermedius 'Argenteomarginatus' had a benefit of $\approx 22.0^{\circ} \mathrm{C}$. Modules planted with $A$. ficoidea 'New Red' had a noontime cooling benefit of $\approx 21.9{ }^{\circ} \mathrm{C}$ in winter, whereas it was $\approx 20.5^{\circ} \mathrm{C}$ in modules planted with $O$. intermedius 'Argenteomarginatus' (Table 3). A two-way repeated measures ANOVA showed that both plant species selection and seasonal variation had a significant impact on the noontime cooling benefit, and there was also a significant interaction between these two variables (Table 4).

The effects of plant characteristics and greening performance on the noontime cooling benefit. The effect of the interaction between season and plant species on the cooling benefit was due to seasonal variations in growth conditions and the greening performances of the plants. Pearson correlation analysis showed that plant height, plant coverage, and albedo were all positively correlated with the cooling benefit; the taller the plants, the more extensive the plant cover, and the larger the albedo, the larger the cooling effect of the EGR module. In addition, the canopy volume was also highly positively correlated with the cooling benefit (Table 5).

The difference between the VWC measured at noontime and the VWC at the saturated stage represented as $\triangle \mathrm{VWC}$. Due to the amount of water retained by the reservoir drainage boards, the daily VWC of each module was quite stable. On average, the $\triangle \mathrm{VWC}$ was $0.003 \mathrm{~m}^{3} \cdot \mathrm{m}^{-3}$. A Pearson correlation analysis found no significant correlation between $\triangle \mathrm{VWC}$ and the cooling benefit ( $r=0.003, P=0.935$ ).

Additionally, a stepwise multiple regression analysis was conducted to examine the effects of $\mathrm{SR}_{\text {in }}$ and of plant characteristics and greening performance on the cooling

Table 3. Mean cooling benefits of the extensive green roof modules planted with the 12 plant species over the course of four seasons.

\begin{tabular}{|c|c|c|c|c|c|c|c|}
\hline \multicolumn{2}{|l|}{ Spring $\Delta \overline{\mathrm{T}}\left({ }^{\circ} \mathrm{C}\right)$} & \multicolumn{2}{|l|}{ Summer $\Delta \overline{\mathrm{T}}\left({ }^{\circ} \mathrm{C}\right)$} & \multicolumn{2}{|l|}{ Autumn $\Delta \overline{\mathrm{T}}\left({ }^{\circ} \mathrm{C}\right)$} & \multicolumn{2}{|l|}{ Winter $\Delta \overline{\mathrm{T}}\left({ }^{\circ} \mathrm{C}\right)$} \\
\hline Codiaeum variegatum var. pictum & 25.3 & O. japonicus 'Nanus' & 28.1 & Se. lineare 'Variegatum' & 23.4 & Sa. trifasciata 'Laurentii' & 21.6 \\
\hline Wedelia trilobata (L.) Hitchc. & 25.2 & B. chinensis & 28.1 & C. variegatum var. pictum & 23.1 & $\begin{array}{l}\text { O. intermedius } \\
\text { 'Argenteo-marginatus' }\end{array}$ & 21.3 \\
\hline $\begin{array}{l}\text { Ophiopogon intermedius } \\
\text { 'Argenteo-marginatus' }\end{array}$ & 25.1 & P. amboinicus & 28.0 & P. amboinicus & 23.0 & P. amboinicus & 21.3 \\
\hline Schizocentron elegans & 24.9 & A. ficoidea 'New Red' & 28.0 & Z. pendula Schnizl. & 22.9 & W. trilobata (L.) Hitchc. & 21.3 \\
\hline Sansevieria trifasciata 'Laurentii' & 24.1 & T. violacea & 27.6 & T. violacea & 22.8 & T. violacea & 21.2 \\
\hline Sedum lineare 'Variegatum’ & 24.0 & $\begin{array}{l}\text { O. intermedius } \\
\text { 'Argenteo-marginatus' }\end{array}$ & 27.6 & W. trilobata (L.) Hitchc. & 22.8 & B. chinensis & 21.0 \\
\hline Zebrin & 23.9 & W. trilobata (L.) Hitchc. & 27.6 & O. japonicus 'Nanus' & 22.5 & Z. pe & 20.8 \\
\hline Ophiopogon japonicus 'Nanus' & 23.6 & Sc. elegans & 27.5 & O. intermedius 'Argenteo-marginatus' & 22.0 & O. japonicus 'Nanus' & 20.5 \\
\hline
\end{tabular}

The analysis period was 11:00 to 13:00. 
Table 4. Two-way repeated measures analysis of variance of the effects of plant species selection and seasonal variation on the noontime cooling benefit.

\begin{tabular}{lcccrr}
\hline Source & $\begin{array}{c}\text { Type III sum } \\
\text { of squares }\end{array}$ & df & Mean square & \multicolumn{1}{c}{ F } & $* * *$ \\
\hline Season & $2,622.712$ & 1.104 & $2,374.757$ & 97.650 & $* * *$ \\
Plant species & 20.587 & 1.972 & 10.440 & 8.584 & $* * *$ \\
Season $\times$ plant & 62.211 & 2.443 & 25.465 & 50.564 & \\
$\quad$ species & & & & &
\end{tabular}

The analysis period was 11:00 to 13:00.

***refers to $P<0.001$; ** refers to $P<0.01$.

Table 5. Pearson correlation analysis $(r)$ of the relations between plant characteristics and greening performance and noontime cooling benefit.

\begin{tabular}{lcc}
\hline $\begin{array}{l}\text { Plant characteristics and } \\
\text { greening performance }\end{array}$ & \multicolumn{2}{c}{$r$} \\
\hline Plant height & 0.159 & $* * *$ \\
Plant coverage & 0.090 & $*$ \\
Albedo & 0.323 & $* * *$ \\
Canopy volume & 0.165 & $* * *$ \\
\hline
\end{tabular}

The analysis period was 11:00 to 13:00.

*** refers to $P<0.001$; * refers to $P<0.05$.

Table 6. Stepwise multiple regression analysis of the effects of plant characteristics and greening performance and radiation intensity on the noontime cooling benefit.

\begin{tabular}{lccc}
\hline & $B$-coefficient & Standardized \\
& coefficient & $t$ \\
\hline Constant & 9.338 & & $* * *$ \\
SR $_{\text {in }}$ & 0.019 & 0.807 & $* * *$ \\
Albedo & 8.663 & 0.069 & $* *$ \\
Canopy & 0.017 & 0.051 & $*$ \\
$\quad$ volume & & & \\
$R^{2}=0.703$ & $F=448.057 * * *$ & & \\
\hline
\end{tabular}

The analysis period was 11:00 to $13: 00$.

*** refers to $P<0.001$; ** refers to $P<0.01$;

* refers to $P<0.05$.

benefit. The results showed that the higher $\mathrm{SR}_{\mathrm{in}}$, the higher the albedo of the module, and the greater the canopy volume of the module, the larger the noontime cooling benefit. The $\mathrm{SR}_{\text {in }}$ had the most significant influence followed by the albedo and the canopy volume of the module (Table 6).

\section{Discussion}

Radiation intensity, plant species, and cooling benefit. The results of this study showed a significant linear and positive relationship between the cooling benefit and radiation intensity; larger quantities of radiation resulted in more significant EGR cooling benefits (Fig. 8). The results consisted with studies conducted in Hong Kong and Japan that found that intense solar radiation can pronounce the cooling effect of EGRs (Jim and Peng, 2012; Peng and Jim, 2015; Tabares-Velasco and Srebric, 2011).

In this study, the cooling benefit of an EGR was relatively large during the seasons and at the times of day when there was relatively strong $\mathrm{SR}_{\mathrm{in}}$. Therefore, an EGR had a greater cooling effect and a greater temperature-stabilizing capacity at times when there was relatively higher solar radiation, so for a location with high solar radiation intensity, a more sophisticatedly designed EGR could be expected to contribute more cooling benefits.

This study also demonstrated that the cooling benefits of the modules planted with different plant species were significantly different at any given time of day (data not shown), but these differences were unafdifferent cooling effects of different plants resulted from their inherent, species-specific characteristics. The study results reconfirmed that plant selection is a crucial aspect influencing the magnitude of the cooling effect of an EGR (Blanusa et al., 2013; Lin, 2010; Wong et al., 2007; Zhao et al., 2014).

Effects of seasonal variation and greening performance on cooling benefit. In response to the lack of studies investigating the seasonal and diurnal patterns of the thermal performance of EGRs, Peng and Jim (2015) conducted monitoring for a 2-year period: 1 year before roof greening and 1 year after. In their study, Arachis pintoi (perennial peanut) was the only plant species used, and the study results indicated notable seasonal and diurnal patterns in EGR thermal performance. The present study further identified the effects of plant selection and seasonal variation on the cooling effects of EGRs.

This study indicated that the inherent characteristics of plants and their seasonal variation in greening performance are both key factors in the selection of plant species to create an EGR with better cooling benefits. Plants with greater canopy volume provided a larger shaded area, which meant that less solar radiation reached the substrate surface. The results also confirmed the findings of studies indicating that EGRs with higher plant coverage (D'Orazio et al., 2012; TabaresVelasco and Srebric, 2011; Yaghoobian and Srebric, 2015) and larger LAI (Olivieri et al., 2013; Tabares-Velasco and Srebric, 2011) had greater cooling effects.

Plants had higher albedos which meant that more SR was reflected into the atmosphere, so less radiation was absorbed by or transmitted to the modules, lowering temperatures and confirming the results of D'Orazio et al. (2012) and Takebayashi and Moriyama (2007). In other words, plant species with foliage cover that persisted for a relatively long period of time after greening, that had bright leaf and flower colors as well as long flowering periods also had higher albedos and therefore provided greater cooling effects.

Plant selection for EGR. From the applied perspective, this study intended to propose fected by radiation intensity (Fig. 8). The criteria to select ornamental plants for EGR that have optimal noontime cooling performances overall four seasons. The noontime cooling benefits and the rankings of the 12 plant species over the four seasons were further compared by calculating the cumulative ranking, the cumulative cooling difference from the previous season, and the variance in the cooling difference between the previous and current season of the 12 plant species (data not shown). Although the sample size was insufficient to propose a clear and well-developed set of criteria, three plants types could be suggested for use in EGRs based on the results of the present study.

The first type of plant exhibited excellent noontime cooling effects in all four seasons, and $P$. amboinicus was an example. The $P$. amboinicus plants were relatively tall and had relatively extensive and stable plant coverages and high albedos during all four seasons. The second type of plant had relatively poor cooling benefit rankings in spring but better noontime cooling benefit rankings in summer, autumn, and winter; A. ficoidea 'New Red', Sa. trifasciata 'Laurentii', and Se. lineare 'Variegatum' were examples of this type. The plant height, plant coverage, canopy volume, and albedo of these plants increased significantly during the peak growth periods of summer and autumn. The third type of plant exhibited extremely large variations in noontime cooling benefit rankings over the four seasons, and $Z$. pendula Schnizl. and B. chinensis were examples of this type. The noontime cooling benefit of $Z$. pendula Schnizl. ranked 11th in spring, $1 \mathrm{st}$ in summer, 6th in autumn, and 11th in winter, and this large variation was related to its growth and greening performance. Furthermore, Z. pendula Schnizl. grew better in summer than in other seasons, and its growth was better overall than that of the other plant species, which resulted in Z. pendula Schnizl. providing a very good noontime cooling benefit in summer.

According to the results of this study, the first and second types of plant species would be recommended for an EGR designed to have a better cooling effect. Among the 12 plant species studied, $P$. amboinicus, $A$. ficoidea 'New Red', Sa. trifasciata 'Laurentii', and Se. lineare 'Variegatum' would be included. However, more plant species must be studied to provide more comprehensive recommendations for green roof vegetation. Additional research aimed at categorizing ornamental plants for use in EGRs in terms of their noontime cooling performances overall four seasons are especially required.

Based on the results of previous studies (Fernandez-Cañero et al., 2013; Loder, 2014), the willingness of the public to construct a green roof is influenced by its visual aesthetics. Therefore, the present study focused on 12 plant species with relatively high ornamental value for an entire year and linked their characteristics and greening performance to their cooling benefits. To quantify the cooling performances of EGRs 
planted with the 12 plant species studied, a monoculture approach was adopted, but diverse planting schemes could increase the ecological services provided by a green roof (Cook-Patton and Bauerle, 2012). Therefore, more research aimed at understanding the multiple benefits of combination planting is required. In addition, long-term study is especially needed to document and analyze the multiple benefits of EGRs more comprehensively.

\section{Conclusions}

This study investigated the cooling performances on rainless days of EGRs planted with different ornamental plants in a subtropical city to suggest criteria for plant species selection. The results supported the following conclusions:

- The cooling benefit of an EGR was greater when the quantity of the $\mathrm{SR}_{\text {in }}$ was greater. However, the amplitude of the difference in the cooling benefits of EGRs planted with different plant species was unaffected by radiation intensity.

- Noontime was the period during which an EGR exhibited its highest cooling benefit during the day. This noontime cooling benefit varied with season and the species planted.

- An EGR planted with species with higher greening performance over four seasons resulted in a greater noontime cooling effect. Therefore, it is necessary to use plant species with appropriate levels of greening performance throughout all four seasons in areas that require cooling. Brighter leaf color, taller height, higher coverage, and greater canopy volume were the main characteristics for plant species selection.

\section{Literature Cited}

Baik, J.J., K.H. Kwak, S.B. Park, and Y.H. Ryu. 2012. Effects of building roof greening on air quality in street canyons. Atmos. Environ. 61:48-55.

Benvenuti, S. 2014. Wildflower green roofs for urban landscaping, ecological sustainability and biodiversity. Landsc. Urban Plan. 124: 151-161.

Bevilacqua, P., J. Coma, G. Pérez, C. Chocarro, A. Juárez, C. Solé, M. De Simone, and L.F. Cabeza. 2015. Plant cover and floristic composition effect on thermal behaviour of extensive green roofs. Build. Environ. 92:305-316.

Bevilacqua, P., D. Mazzeo, R. Bruno, and N. Arcuri. 2016. Experimental investigation of the thermal performances of an extensive green roof in the Mediterranean area. Energy Build. 122:63-79.

Blanusa, T., M.M. Vaz Monteiro, F. Fantozzi, E. Vysini, Y. Li, and R.W.F. Cameron. 2013. Alternatives to Sedum on green roofs: Can broad leaf perennial plants offer better 'cooling service'? Build. Environ. 59:99-106.

Buckland-Nicks, M., A. Heim, and J. Lundholm. 2016. Spatial environmental heterogeneity affects plant growth and thermal performance on a green roof. Sci. Total Environ. 553:20-31.

Central Weather Bureau. 2012-13. Monthly report on climate system. Taipei, Taiwan.

Chang, C.U. 2004. Landscape plants. Sun Sin publisher, Taipei, Taiwan.
Cook-Patton, S.C. and T.L. Bauerle. 2012. Potential benefits of plant diversity on vegetated roofs: A literature review. J. Environ. Mgt. 106:85-92.

D’Orazio, M., C.D. Perna, and E.D. Giuseppe. 2012. Green roof yearly performance: A case study in a highly insulated building under temperate climate. Energy Build. 55:439-451.

Dunnett, N. and N. Kingsbury. 2004. Planting green roofs and iving walls. Timber Press, Inc., Portland, OR.

Dvorak, B. and A. Volder. 2013. Rooftop temperature reduction from unirrigated modular green roofs in south-central Texas. Urban For. Urban Gree. 12:28-35.

Fernandez-Cañero, R., T. Emilsson, C. FernandezBarba, and M.Á. Herrera Machuca. 2013. Green roof systems: A study of public attitudes and preferences in southern Spain. J. Environ. Mgt. 128:106-115.

Francis, R.A. and J. Lorimer. 2011. Urban reconciliation ecology: The potential of living roofs and walls. J. Environ. Mgt. 92:1429-1437.

Gedge, D. and G. Kadas. 2005. Green roofs and biodiversity. Biologist 52:161-169.

Getter, K.L. and B.D. Rowe. 2006. The role of extensive green roofs in sustainable development. HortScience 41:1276-1285.

Getter, K.L., D.B. Rowe, J.A. Andresen, and I.S. Wichman. 2011. Seasonal heat flux properties of an extensive green roof in a Midwestern U.S. Energy Build. 43:3548-3557.

Hsueh, C.H. and Z.Y. Yang. 2014. The scenic plants in Taiwan. Hsueh Chung Hsien publisher, Taipei, Taiwan.

Jim, C.Y. 2014. Heat-sink effect and indoor warming imposed by tropical extensive green roof. Ecol. Eng. 62:1-12.

Jim, C.Y. and L.L.H. Peng. 2012. Weather effect on thermal and energy performance of an extensive tropical green roof. Urban For. Urban Green. 11:73-85.

Jun, Y., Y. Qian, and G. Peng. 2008. Quantifying air pollution removal by green roofs in Chicago. Atmos. Environ. 42:7266-7273.

Jungels, J., D.A. Rakow, S.B. Allred, and S.M. Skelly. 2013. Attitudes and aesthetic reactions toward green roofs in the Northeastern United States. Landsc. Urban Plan. 117:13-21.

Kumar, R. and S.C. Kaushik. 2005. Performance evaluation of green roof and shading for thermal protection of buildings. Build. Environ. 40:1505-1511.

Lee, K.E., K.J.H. Williams, L.D. Sargent, C. Farrell, and N.S. Williams. 2014. Living roof preference is influenced by plant characteristics and diversity. Landsc. Urban Plan. 122:152-159.

Lin, B.S. 2010. The cooling effects of plant and green land. Graduate Institute of Horticulture, National Taiwan University, Taipei, Taiwan, Doctoral Dissertation.

Lin, B.S. and Y.J. Lin. 2010. Cooling effect of shade trees with different characteristics in a subtropical urban park. HortScience 45:83-86.

Lin, B.S., C.C. Yu, A.T. Su, and Y.J. Lin. 2013. Impact of climatic conditions on the thermal effectiveness of an extensive green roof. Build. Environ. 67:26-33.

Loder, A. 2014. There's a meadow outside my workplace: A phenomenological exploration of aesthetics and green roofs in Chicago and Toronto. Landsc. Urban Plan. 126:94-106.

Lundholm, J.T. 2015. Green roof plant species diversity improves ecosystem multifunctionality. J. Appl. Ecol. 52:726-734.

Lundholm, J.T., B.M. Weddle, and J.S. MacIvor. 2014. Snow depth and vegetation type affect green roof thermal performance in winter. Energy Build. 84:299-307.
Madre, F., A. Vergnes, N. Machon, and P. Clergeau. 2014. Green roofs as habitats for wild plant species in urban landscapes: First insights from a largescale sampling. Landsc. Urban Plan. 122:100-107.

Mentens, J., D. Raes, and M. Hermy. 2006. Green roofs as a tool for solving the rainwater runoff problem in the urbanized 21 st century? Landsc. Urban Plan. 77:217-226.

Olivieri, F., C.D. Perna, M. D’Orazio, L. Olivieri, and J. Neila. 2013. Experimental measurements and numerical model for the summer performance assessment of extensive green roofs in a Mediterranean coastal climate. Energy Build. 63:1-14.

Olsoy, P.J., J.J. Mitchell, D.F. Levia, P.E. Clark, and N.F. Glenn. 2015. Estimation of big sagebrush leaf area index with terrestrial laser scanning. Ecol. Indic. 61:815-821.

Peng, L.L.H. and C.Y. Jim. 2015. Seasonal and diurnal thermal performance of a subtropical extensive green roof: The impacts of background weather parameters. Sustainability 7:11098-11113.

Razzaghmanesh, M., S. Beecham, and F. Kazemi. 2014. Impact of green roofs on stormwater quality in a South Australian urban environment. Sci. Total Environ. 470-471:651-659.

Rowe, D.B. 2011. Green roofs as a means of pollution abatement. Environ. Pollut. 159:2100-2110.

Sailor, D.J. 2008. A green roof model for building energy simulation programs. Energy Build. 40:1466-1478.

Schroll, E., J. Lambrinos, T. Righetti, and D. Sandrock. 2011. The role of vegetation in regulating stormwater runoff from green roofs in a winter rainfall climate. Ecol. Eng. 37: 595-600.

Stovin, V., S. Poë, S. De-Ville, and C. Berretta. 2015. The influence of substrate and vegetation configuration on green roof hydrological performance. Ecol. Eng. 85:159-172.

Tabares-Velasco, P.C. and J. Srebric. 2011. Experimental quantification of heat and mass transfer process through vegetated roof samples in a new laboratory setup. Intl. J. Heat Mass Transfer 54:5149-5162.

Takebayashi, H. and M. Moriyama. 2007. Surface heat budget on green roof and high reflection roof for mitigation of urban heat island. Build. Environ. 42:2971-2979.

The Taipei Hsi Liu Environmental Greening Foundation. 2007. You can have a green roof. Taipei, Taiwan.

Tong, Z., T.H. Whitlow, A. Landers, and B. Flanner. 2016. A case study of air quality above an urban roof top vegetable farm. Environ. Pollut. 208:256-260.

Van Mechelen, C., T. Dutoit, J. Kattge, and M. Hermy. 2014. Plant trait analysis delivers an extensive list of potential green roof species for Mediterranean France. Ecol. Eng. 67:48-59.

White, J.W. and E. Snodgrass. 2003. Extensive green roof plant selection and characteristics, $\mathrm{p}$. 166-176. In: Proceeding of 1st North American green roof infrastructure conference, awards and trade show. Toronto, Canada.

Wong, N.H., P.Y. Tan, and Y. Chen. 2007. Study of thermal performance of extensive rooftop greenery systems in the tropical climate. Build. Environ. 42:25-54.

Yaghoobian, N. and J. Srebric. 2015. Influence of plant coverage on the total green roof energy balance and building energy consumption. Energy Build. 103:1-13.

Zhao, M., P.C. Tabares-Velasco, J. Srebric, S. Komarneni, and R. Berghage. 2014. Effects of plant and substrate selection on thermal performance of green roofs during the summer. Build. Environ. 78:199-211. 